\title{
INVESTIGATION OF THE INFLUENCE OF ANTIMICROBIAL PREPARATIONS ON THE SHELF LIFE OF BROCCOLI CABBAGE
}

\author{
Ludmila Pusik \\ Department of technologies of processing of food production \\ Kharkiv Petro Vasylenko National Technical University of Agriculture \\ 44 Alchevskyh str., Kharkiv, Ukraine, 61002 \\ Ludmilap@gmail.com \\ Vladimir Pusik \\ Department of Agrotechnology and Ecology \\ Kharkiv Petro Vasylenko National Technical University of Agriculture \\ 44 Alchevskyh str., Kharkiv, Ukraine, 61002 \\ kysmish@gmail.com \\ Nina Lyubymova \\ Department of Agrotechnology and Ecology \\ Kharkiv Petro Vasylenko National Technical University of Agriculture \\ 44 Alchevskyh str., Kharkiv, Ukraine, 61002 \\ nina.lioubimova@gmail.com \\ Veronika Bondarenko \\ Department of fruit and vegetable and storage \\ Kharkiv National Agricultural University named after V. V. Dokuchayev \\ "Dokuchaevske - 2", Kharkiv region, Ukraine, 62483 \\ zim-hot@rambler.ru \\ Ludmila Gaevaya \\ Department of fruit and vegetable and storage \\ Kharkiv National Agricultural University named after V. V. Dokuchayev \\ “Dokuchaevske - 2", Kharkiv region, Ukraine, 62483 \\ Gaevaaludmila9@gmail.com
}

\footnotetext{
Abstract

Studies of the effect of antimicrobial agents on the conservation of broccoli cabbage have been conducted. The late hybrids of broccoli Ironman F1, Agassi F1, Beaumont F1, grown under the conditions of the Forest-Steppe of Ukraine were studied. The content of the main components of the chemical composition (dry substances, dry soluble substances, sugars, vitamin C) of broccoli cabbage is analyzed depending on the characteristics of the hybrid. The effect of antimicrobial treatment on the natural loss of cabbage, microbiological lesions during storage has been studied. Antimicrobial preparations Baikal EM-1 (dilution of working solution in water 1: 500), $0.5 \%$ solution of citric, $0.2 \%$ benzoic, $0.05 \%$ sorbic acid, and also $0.5: 0.5 \%$ solution of vitamins $\mathrm{C}$ and $\mathrm{P}$ (ascorutin), water for the preparation of solutions had a temperature of $23 \ldots .25^{\circ} \mathrm{C}$.

The processing of fruit and vegetable products with various chemicals is aimed at prolonging the shelf life, increasing the shelf life and increasing the yield of commercial products at the end of storage.

It is established that the natural loss of broccoli cabbage during storage depends on the characteristics of the hybrid and the type of antimicrobial preparation. Treatment with preparations increases the shelf life of broccoli cabbage to 30-50 days with a natural weight loss of up to $6.1 \%$, and ensures minimal disease burden.

Treatment with antimicrobial agents reduces the loss of dry substances, dry soluble substances, sugars, vitamin C. The most effective is the treatment of broccoli with acids. It has been established that ascorbic acid is contained in broccoli cabbage, with hydrolysis from which ascorbic acid is split off, the content of which is increased.

The maximum effective storage of broccoli cabbage at a temperature of $0 \pm 1 \mathrm{oC}$ and relative humidity of $90-95 \%$, pretreatment with preparations of antimicrobial action.

The proposed method of processing broccoli cabbage with antimicrobial preparations before storage allows the use of vegetable
} 
raw materials for post-harvest treatment. In the development of new, low-cost, environmentally friendly and affordable storage technologies, this is an important technique.

Keywords: antiseptics, components of chemical composition, shelf life, storage losses, commercial products.

\section{Introduction}

The homeland of broccoli is Italy, where it has the greatest variety of forms. In the 18th century, this cabbage was imported into Germany, and from there it came to Ukraine. The young broccoli cabbage leaves are equivalent to spinach and cabbage. By taste, broccoli resembles asparagus and is characterized by high levels of vitamin $U$ (with vegetables this vitamin is more only in asparagus). In broccoli, much more vitamins and mineral salts than cabbage are colored. By its chemical composition, it occupies a leading place not only among varieties of cabbage, but also among other vegetable plants [1]. The protein in it contains from 3.2 to $5.9 \%$, whereas in color $-2.2 \%$, and in the white-footed one $-1.2 \%$, by quantity and quality of protein is equal to chicken egg. By the content of the essential amino acids, broccoli can be equated to beef, and by the presence of lysine, tryptophan and isoleucine - up to chicken meat. Also contains a dry substance $-8.7-11.2 \%$, sugar: the sum $-1.5-3.8 \%$, sucrose from the total amount of sugars $5-10 \%$; starch $-0.45 \%$; fiber $-0.7-1.2 \%$ on the raw material. In comparison with cauliflower in broccoli, vitamin $\mathrm{C}$ is in 2.8-3.0 times and dry matter is 2.0-2.7 times more. Broccoli is rich in sugars, it accumulates more methionine, and purine substances, which are harmful to patients with gout and kidney stones, are 4 times less. The broccoli fiber promotes the cleansing of the human body from radionuclides [2-4]. The protein of this plant includes anti-sclerotic substances methionine, choline, lysine and isoleucine, which prevent the accumulation of cholesterol in the body and prevent it from premature aging. Due to these valuable properties abroad, broccoli are used to treat radiation sickness, as well as pollen, formed in buds at the beginning of flowering, are used for this purpose. Broccoli is recommended to be consumed in food for the prevention and treatment of atherosclerosis, cardiovascular diseases, nervous disorders, various diseases of the stomach and liver [5-7].

The heads of broccoli are laid for storage in the technical ripeness phase for 5-7 days at a temperature of $1 \ldots 2^{\circ} \mathrm{C}[8,9]$. At $0{ }^{\circ} \mathrm{C}$ and relative air humidity of $90-95 \%$, they can be stored for up to 10 days. With longer storage, the leaves become discolored, the tissues soften. R. B. Jones et al. [10] recommend storing broccoli cabbage at a temperature of $4{ }^{\circ} \mathrm{C}$ and a relative humidity of 98-100 \%. M. C. N. Nunes and J. P. Emond [11] advised to store broccoli cabbage at a temperature of $0{ }^{\circ} \mathrm{C}$. The relative humidity of air for broccoli should be $95-100 \%$. Under such conditions, broccoli sprouts 10-14 days, Brussels - 3-5 weeks, cauliflower - 3-4 weeks. The processing of fruit and vegetable products with various chemicals is aimed at improving the shelf life and increasing the yield of commercial products at the end of storage, increasing the shelf life of the broccoli cabbage is treated with antimicrobial agents.

The aim of research is analysis of the content and variation of the components of the chemical composition of broccoli cabbage during storage. Determine the natural-loss of production and loss from microbiological damage, depending on the treatment with antimicrobial preparations.

\section{Materials and methods}

Research was carried out in the laboratory of the Department of Fruit and Vegetable Production and Storage of the Kharkiv National Agrarian University named after V.V. Dokuchaev (Ukraine). Late ripened broccoli cabbage hybrids (Ironman $\mathrm{F}_{1}$, Agassi $\mathrm{F}_{1}$, Beaumont $\mathrm{F}_{1}$ ), grown under the conditions of the Forest-Steppe of Ukraine, were investigated. Broccoli was harvested when the heads acquired the technical ripeness, size and density characteristic of a particular hybrid. The diameter of the broccoli cabbage head was not less than $4 \mathrm{~cm}$ according to the standard. Before storing the cabbage heads, the broccoli was cooled to storage temperature. The cabbage was stored in a refrigerated chamber of Polair Standard $\mathrm{KXH}-8.81$ at a temperature of $0 \pm 1{ }^{\circ} \mathrm{C}$ and 
relative humidity of $90-95 \%$ in boxes of film lined with polyethylene with a thickness of $40 \mu \mathrm{m}$, the edges of the film were tightly wrapped in the form of an envelope (Fig. 1, 2).
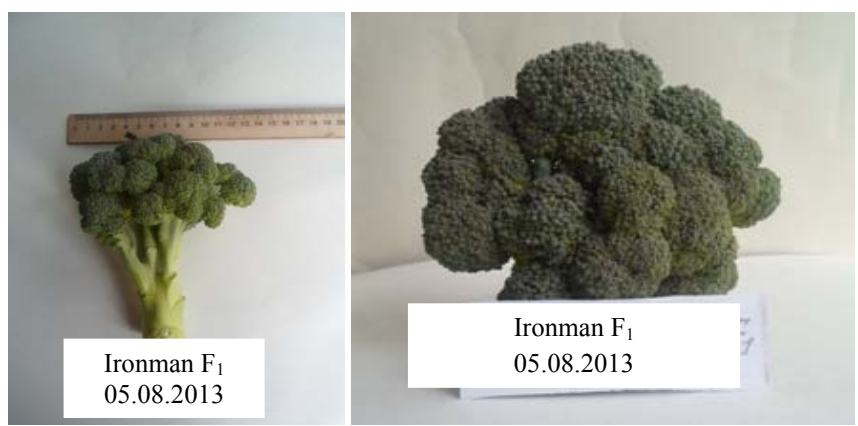

$a$



Agassi $\mathrm{F}_{1}$ 05.08.2013

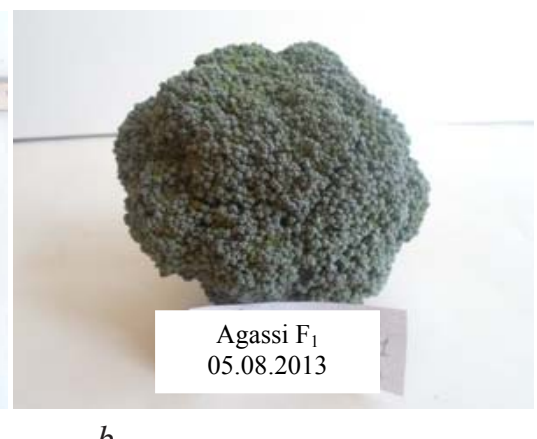

$b$

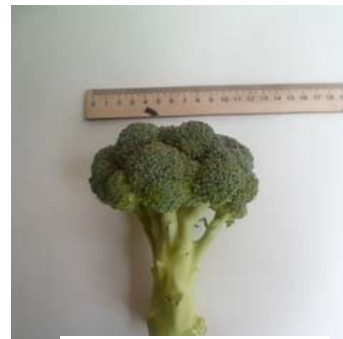

Beaumont $\mathrm{F}_{1}$

05.08.2013

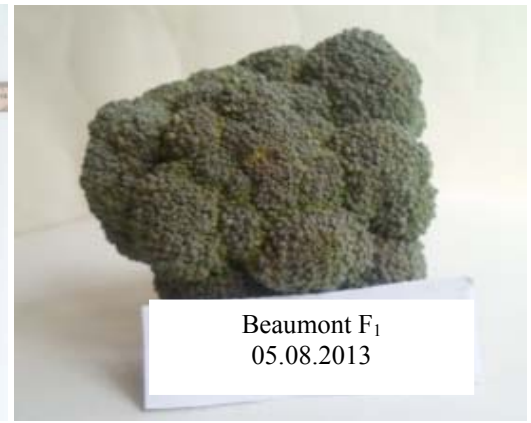

Fig. 1. Appearance of the broccoli cabbage head: $a$ - Ironmen $\mathrm{F}_{1}$ hybrid; $b$-Agassi $\mathrm{F}_{1}$ hybrid; $c$ - Beaumont $\mathrm{F}_{1}$ hybrid



Fig. 2. Appearance of field experiment 
When studying the effect of antimicrobial preparations on the quality of cabbage, Baikal EM-1 (dilution of working solution in water 1:500), $0.5 \%$ lemon solution, $0.2 \%$ benzoin, $0.05 \%$ sorbic acid, as well as 0,5: 0,5\% solution of vitamins $\mathrm{C}$ and $\mathrm{P}$ (ascorutin), water for the preparation of solutions had a temperature of $23-25^{\circ} \mathrm{C}$. The treatment of cabbage with preparations of antimicrobial action was carried out by immersion in aqueous solutions for 20-30 seconds, after which the heads were dried with a fan and cooled to storage temperature. The cabbage was stored in a refrigerated chamber of Polair Standard KXH-8.81 at a temperature of $0 \pm 1{ }^{\circ} \mathrm{C}$ and relative humidity of $90-95 \%$. The average sample weight is $4 \mathrm{~kg}$. Observation of broccoli was carried out in dynamics every 5 days. During storage, it was determined: natural weight loss, commercial quality. The content of dry substances was determined by drying in a drying cabinet, the mass fraction of dry soluble substances on a refractometer (Fig. 3).



$a$

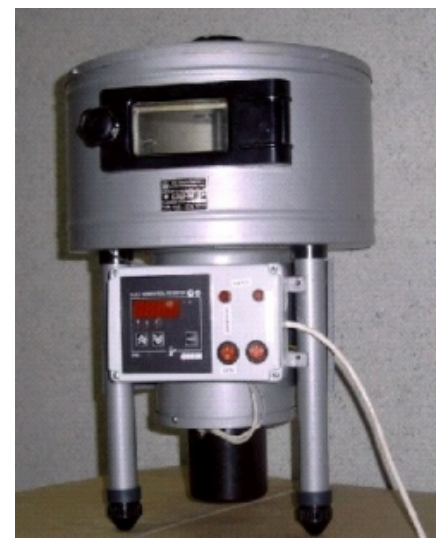

$b$

Fig. 3. Instruments for determining the content of dry and soluble substances: $a$ - refractometer УРЛ- $1 ; b$ - drying cabinet

Characteristics of preparations. Citric acid is colorless crystals or white powder, registered as a food additive with code E 330. Used in the food industry as a synthetic antioxidant and acidity regulator, color stabilizer, hydrolysis catalyst, as well as synergists of antioxidants. When heated more than $175^{\circ} \mathrm{C}$ decomposes into carbon dioxide and water.

One of the main characteristics of citric acid is the property of protecting products from the effects of heavy metals by forming complex compounds with them. Therefore, citric acid is widely used in fat-and-oil industry, thus significantly reducing the likelihood of giggling fats and margarines.

Now food citric acid is obtained by fermentation of sugar-containing media (beet pulp, sugar) by industrial strains of mold fungus Aspergillus niger, or by fermentation of sweet waste of sugar production - molasses. In addition, citric acid is isolated from plant raw materials - lemons, tobacco leaves, pineapple wastes [12, 13].

Sorbic acid is a food additive-preservative (code E 200). It has an effective antimicrobial effect. Suppress the growth of most microorganisms, especially yeast, molds, fewer bacteria. Contained in the juice of mountain ash (Sorbus aucuparia), from which it was first obtained in 1859. It does not change the taste and smell of products and in the concentrations used for preserving food, it is not toxic to humans. The inhibiting effect of sorbic acid against yeast is manifested at $\mathrm{pH}$ of the medium 3.0-5.7; mold fungi - 2,5-5,7 [14].

At present, sorbic acid on an industrial scale is obtained by condensing ketene with croton aldehyde using acid catalysts. The main products that use sorbic acid include juices, soft drinks, confectionery and bakery products, granular caviar, sausages, condensed milk and other products $[15,16]$.

Benzoic acid is a food additive-preservative with code E 210, is a white crystalline powder with a characteristic odor. Used in the manufacture of beverages, fruit and berry products, fish products. In nature it is found in cranberries, cowberries, black currants, plums, anise oil, etc. In 
industry, it is obtained by the method of oxidation of toluene (methylbenzene) with the participation of catalysts. Prevents reproduction of mold, yeast and bacteria of fermentation oil. Antimicrobial action is based on direct inhibition of the activity of microbial cell enzymes and inhibition of the action of catalase and peroxidase, resulting in the accumulation of hydrogen peroxide in the cells of microorganisms. Benzoic acid is most effective in acidic medium (it operates at $\mathrm{pH} 2.6-5.0$ against yeast, against mold fungi at $\mathrm{pH}$ 2.6-5.1, at $\mathrm{pH} 5.6$ the whole acid undergoes dissociation), and in neutral and alkaline solutions, its effect is almost not manifested. There is no cumulation of benzoic acid in the body, therefore it is considered as a relatively harmless compound [14, 17-20].

Baikal EM-1 - the preparation is available as a concentrate in packs of 40 and $14 \mathrm{ml}$ with a holographic sticker and logo. Shelf life is 1 year. The composition of the preparation includes about 60 strains of living microorganisms, which together constitute a stable symbiosis. In concentrate they are at rest. The largest groups of microorganisms that make up the EM preparation are photosynthetic and lactic acid bacteria, yeast, actinomycetes and fermentable fungi of the Aspergillus and Penicillium type [21].

Ascorutin is a combined preparation containing water-soluble vitamins $\mathrm{C}$ and $\mathrm{P}$ (rutin). It is produced in the form of coated tablets.

In a plant organism, ascorbic acid acts as an integrated part of its own antioxidant cell defense system, including both enzymes and low-molecular compounds, which can lead to an increase in the antioxidant properties of the organism as a whole. It actively inhibits the peroxidation process. Vitamin $\mathrm{C}$ is a strong reducing agent and, being oxidized and recovering easily, functions as an important cellular redox system. It functions not only as an antioxidant, but also has a preserving effect on other antioxidants. Rutin (belongs to the group of bioflavonoids), together with ascorbic acid, participates in reducing oxidative processes, has antioxidant properties, in particular, prevents oxidation of ascorbic acid [22, 23]. Vitamins C and P are interrelated in the metabolism - one enhances the effect of the other [24]. Ascorbic acid with external application acts as an antioxidant. It is intensively oxidized. At the same time, it loses its C-vitamin activity and at the same time prevents the oxidation of raw materials. During storage, ascorbic acid is destroyed.

Changes in the total content of sugars and reducing sugars were carried out by photocolorimetric (ferricyanide) method. The content of sucrose was determined as the difference between the total content of sugars and reducing sugars multiplied by a factor of 0.95 . When determining some components of the chemical composition for the purpose of comparing the results during storage, the content of the substances was recalculated, corrected for the loss of mass. The natural weight loss was determined as a percentage of the original mass. The sample was withdrawn for storage if the natural weight loss reached $10 \%$ or more and the production had signs of disease and physiological disorders. At the end of storage, the yield of standard products was determined. Identification of pathogens of microbiological diseases was carried out according to the morphology of the pathogen under the microscope.

\section{Research results}

It is established that the natural loss of cabbage mass during storage depends on the characteristics of the hybrid and the type of antimicrobial preparation. In the variant without treatment with preparations, they were from 3.7 to $4.8 \%$, depending on the hybrid for 25-40 days of storage. Treatment with preparations extended the shelf life of cabbage to 30-50 days with total weight loss to $6.1 \%$.

The most harmful during storage of fungal diseases are (gray and white molds, phomosis) and bacterial (vascular mucous bacteriosis). It should be noted that the treatment of cabbage with Baikal EM-1, citric acid and ascorutin provides minimal disease damage.

During the storage of products due to physiological processes, the components of its chemical composition are lost. During the storage of broccoli without medication, on average, the dry matter content decreased in the heads of the Ironman $\mathrm{F}_{1}$ hybrid to $11.4 \%$, Agassi $\mathrm{F}_{1}$ down to 10.5 and Beaumont $\mathrm{F}_{1}$ to $11.2 \%$ in five days of storage. Losses of solids during this period in Ironman $\mathrm{F}_{1}$ were $1.0 \%$, in Agassi $\mathrm{F}_{1}$ and Beaumont $\mathrm{F}_{1}$ respectively 1.5 and $1.2 \%$. 
Due to evaporation of moisture on average over the years of research, the weight loss was in Ironmen $\mathrm{F}_{1} 28.0-47.5 \%$, in Agassi $\mathrm{F}_{1} 26.9-43.7 \%$ and in Beaumont $\mathrm{F}_{1} 30.8-49.1 \%$, depending on preparation, which was more than the control in 1.2-1.9 times.

The use of antimicrobial agents reduced the loss of dry substances, dry soluble substances, sugars, vitamin $\mathrm{C}$ by reducing the intensity of respiration. On average, over the years of research, the content of total sugar in the middle of storage in versions with preparations decreased by $0.3-0.6 \%$ compared to the beginning in Ironman $\mathrm{F}_{1}$, by $0.4-0.6 \%$ in Agassi $\mathrm{F}_{1}$ and by $0.2-0.5 \%$ in Beaumont $\mathrm{F}_{1}$ depending on the preparation. The greatest impact was on acid treatment.

Vitamin $\mathrm{C}$ is easily oxidized and restored, this determines its importance in the metabolism. Oxidized form - dehydroascorbic acid - is also physiologically active. The bound form is ascorbigen, which has the physiological activity of vitamin C. Cabbage contains a considerable amount of ascorbic acid. At slow hydrolysis, ascorbic acid is cleaved from ascorbic acid, therefore, despite the oxidation of free ascorbic acid, its quantity may not decrease, but even increase. The same was observed in our studies. When stored without finishing, the amount of ascorbic acid increased by $7-8 \%$ in five days compared to the start of storage, depending on the characteristics of the hybrid. During the years of research, it is possible to note that the content of ascorbic acid in the variants with the application of treatment increased until the fifteenth day of storage, after which there was a decrease in its quantity.

\section{Conclusions}

The ability to store in broccoli cabbage depends not only on the storage conditions (temperature, relative humidity of the air), but also on the measures of primary refinement (treatment with antimicrobials). The maximum efficiency of storage of products can be achieved only due to the complex effect of all factors, in practice it can be realized by storing broccoli at a temperature of $0 \pm 1{ }^{\circ} \mathrm{C}$ and a relative humidity of $90-95 \%$ preliminarily treated with antimicrobial preparations.

The use of antimicrobials almost does not require the introduction of changes in the technology of storage of vegetables, so they can be used during post-harvest processing of vegetable products.

Substances of antiseptic action influence the development of pathogens of microbiological diseases. Penetrating into cells of bacteria, yeast, mold fungi, they change the structure of protoplasm and disrupt the metabolic processes in microorganisms, which leads to inhibition of their development and death. As a result, the shelf life of cabbage is increased and losses from microbiological damage are reduced.

The subsequent promising areas of research are the combination of vegetable treatment with antimicrobial agents and film-forming substances. Development of technology for processing broccoli, namely, freezing and pickling is deserved attention.

\section{References}

[1] Kononkov, P. (1992). Brokkoli. Zhivotnovod, 1, 28-30.

[2] Gil, L. S., Pashkovskiy, A. I., Sulima, L. T. (2008). Suchasni tehnologiyi ovochivnitstva zakritogo i vidkritogo gruntu: navch. posibnik. Ch. 2: Vidkritiy grunt. Vinnitsya: Nova Kniga.

[3] Koltunov, V. A. (2004). Yakist plodoovochevoyi produktsiyi ta tehnologiya yiyi zberigannya. Ch. 1. Yakist i zberezhenist kartopli ta ovochiv. Kiyiv: KNTEU.

[4] Grigorovskaya, M. (2004). Kapusta brokkoli. Ogorodnik, 6, 32.

[5] Vmesto apteki - na gryadku. Za pekinskoy kapustoy i brokkoli (2010). Ovoschevodstvo, $3,50-53$.

[6] Smilyanets, N. M. (2001). Brokoli - eliksir molodosti. Dim, sad, gorod, 3, 4-5.

[7] Hounsome, N., Hounsome, B., Tomos, D., Edwards-Jones, G. (2008). Plant Metabolites and Nutritional Quality of Vegetables. Journal of Food Science, 73 (4), R48-R65. doi: https://doi.org/10.1111/j.17503841.2008.00716.x

[8] Fedosiy, I. A. (2009). Kapusta bryusselskaya. Nastoyaschiy hozyain, 12, 22-26.

[9] Toivonen Peter, M. A., Forney, Ch. (2014). Broccoli. Agriculture Handbook. The Commercial Storage of Fruits, Vegetables, and Florist and Nursery Stocks, 66. 
[10] Jones, R. B., Faragher, J. D., Winkler, S. (2006). A review of the influence of postharvest treatments on quality and glucosinolate content in broccoli (Brassica oleracea var. italica) heads. Postharvest Biology and Technology, 41 (1), 1-8. doi: https://doi.org/10.1016/j.postharvbio.2006.03.003

[11] Nunes, M. C. N., Emond, J. P.; Bartz, J. A., \& Brecht, J. K. (Eds.) (2002). Storage temperature. Postharvest physiology and pathology of vegetables. doi: https://doi.org/10.1201/9780203910092.ch8 acid.html

[12] Limonnaya kislota. Available at: http://www.plasma.com.ua/chemistry/chemistry/citric 1?page $=2$

[13] E 330 - Limonnaya kislota (E 330). Available at: http://prodobavki.com/dobavki/E330.htm-

[14] Lyuk, E., Yager, M. (2000). Konservantyi v pischevoy promyishlennosti. Svoystva i primenenie. Sankt-Peterburg: GIORD.

[15] E 200 - Sorbinovaya kislota (E 200). Available at: http://prodobavki.com/dobavki/E200.htm1?page $=$ all

[16] Ovcharova, T. P. (1994). Sorbinovaya kislota - konservant pischevyih produktov. Moscow.

[17] E 210 - Benzoynaya kislota (E 210). Available at: http://prodobavki.com/dobavki/E210.html

[18] Ekologicheskie problemyi pitaniya. Available at: http://works.tarefer.ru/51/101411/index.html

[19] Kulik, M. F., Kaletnik G. M., Ovsienko, A. I. (1992). Konservanti s pozhivnist kormiv. Kiyv: Urozhay.

[20] Zhungietu, G. I. (1982). Hranenie pischevyih produktov i kormov s primeneniem konservantov. Kishinev: Kartya Moldovenyaske.

[21] Rekomendatsiyi po vikoristannyu preparatu "Baykal EM-1". Available at: http://www.em.rpoargo.com/baikal.htm

[22] Gromovaya, V. F., Shapoval, G. S., Mironyuk, I. E., Piven, V. I. (1996). Nekotoryie osobennosti deystviya askorbinovoy kislotyi na okislitelno-vosstanovitelnyie reaktsii s uchastiem kisloroda. Himiko-farmatsevticheskiy zhurnal, 7, 3-5.

[23] Gorbachev, V. V., Gorbacheva, V. N. (2002). Vitaminyi, mikro- i makroelementyi. Minsk: Knizhnyiy Dom; Interpresservis.

[24] Shirokov, E. P., Polegaev, V. I. (1989). Hranenie i pererabotka plodov i ovoschey. Moscow: Agropromizdat. 